Proc. Indian Acad. Sci. (Earth Planet. Sci.), Vol. 90, Number 2, July 1981, pp. 111-123. - Printed in India.

\title{
The Neogene/Quaternary boundary in India: A review
}

\author{
D P AGRAWAL, DK BHATT*, SHEELA KUSUMGAR and \\ R K PANT \\ Physical Research laboratory, Ahmedabad 380009 , India \\ *Geological Survey of India, Lucknow 226007 , India \\ MS received 5 January 1981; revised 30 April 1981
}

\begin{abstract}
The Neogene/Quaternary boundary has been variously defined in different continents. A global review of the problem shows that only the Olduvai event on the palaeomagnetic timescale may provide an universally acceptable isochronous datum for delineating this boundary. The $N / Q$ boundary in the Siwaliks, Kashmir and the Andamans in India is defined in the light of recent research.
\end{abstract}

Keywords. Neogene/Quaternary boundary ; palaeomagnetic data.

\section{Introdaction}

Lyell coined the term 'Pleistocene' in 1839 as a substitute for the term newer Pliocene (Lyell 1833) and included the sediments which contained 90-95\% molluscan species still living. During the Pleistocene many of the living mammals made their first appearance. The onset of the first glaciation was also used as a marker to define the boundary between Pliocene and Pleistocene by geologists working on continental sections.

Recent literature, however, prefers to use the term Neogene/Quaternary boundary in place of the Pliocene/Pleistocene boundary. The Russian workers, however, use Neogene/Anthropogene and interpolate an 'Eopleistocene' stage between the Pliocene and Pleistocene (Gerasimov 1979); this stage marks the first appearance of hominid forms. We will, for the present, use the term Neogene/Quaternary (N/Q) boundary.

In this paper, we propose first to give a historical background of the Neogene/Quaternary boundary problem; global identification of the boundary based upon marine microfossils, terrestrial vertebrates and palaeomagnetism; and finally we deal with the location of the Neogene/Quaternary boundary in Indian sections, both in continental and marine sequences.

\section{Historical background}

Since the last four decades various efforts have been made to define the Neogene/Quaternary boundary with ever greater precision. In 1948, the XVIII International Geological Congress, placed the boundary at the base of 
1,600 $\mathrm{m}$ thick sedimentary section at Le Castella in Calabria (ItaIy), marking the first appearance of deep-water foraminifera Hyalinea balthica and the mollusc Arctica islandica. Thus for the marine N/Q boundary Calabrian fauna were considered distinctive markers, and for the boundary in the continental sequence the Villafranchian fauna, viz. Elephas, Leptobos, Equus, etc., were taken as the markers.

In 1961, the IV INQUA Congress at Warsaw suggested the inclusion of the emergence of man as an additional criterion. But we know today that hominid antiquity in Africa goes beyond $3 \mathrm{~m} . \mathrm{y}$.

In 1972 the INQUA Sub-Commission on the Plio-Pleistocene boundary recommended the following criteria for recognizing this boundary:

(i) At the base of Astian-Piacenzian of the Italian sequence, corresponding to Globorotalia tosaensis Zone (Zone N-21) and at the base of Lower Villafranchian, equivalent to Gauss Normal Epoch.

(ii) At the base of Calabrian corresponding to Globorotalia truncatulinoides Zone (Zone $\mathrm{N}-22$ ) and coinciding with Olduvai Normal Event of Matuyama Reversed Epoch.

(iii) At the base of Glacial Pleistocene coinciding with Biharian and Matu. yama/Brunhes boundary.

The 1977 symposium on the Neogene/Quaternary boundary held at Moscow was dominated by the discussions of the Russian sections (Anon 1977). The various proposals for the Neogene/Quaternary boundary were the following:

(i) At the base of the Bakuan Beds (Cromerian of the West Europe), equivalent to Matuyama/Brunhes boundary.

(ii) At the base of Apsheronian (Upper Villafranchian-Eburonian), equivalent to Gilsa Event.

(iii) At the base af Akchagylian (Lower Villafranchian), equivalent to the upper part of Gilbert Epoch.

In 1979 a similar conference took place at Chandigarh (India) and the discussions were dominated by the Indian geologists, hence by Indian sections, which will be discussed in $\S 4$.

\section{Global perspective of the Neogene/Quaternary boundary}

It is easier to define global $N / Q$ boundary in the marine sediments than in the continental deposits. We will now briefly discuss the N/Q boundary both in the marine sediments and in the continental deposits.

\subsection{Marine evidence}

On the basis of the study of large number of deep sea cores recovered from tropical to polar regions, the following criteria have been suggested (Ericson and Wollin 1964) for delineating the N/Q boundary (figure 1):

(i) Extinction of Discoasters which had abounded for the previous $75 \mathrm{~m} . \mathrm{y}$.

(ii) First appearance of Globorotalia truncatulinoides.

(iii) Extinction of Globigerinoides sacculifer fistulosus above the boundary. 


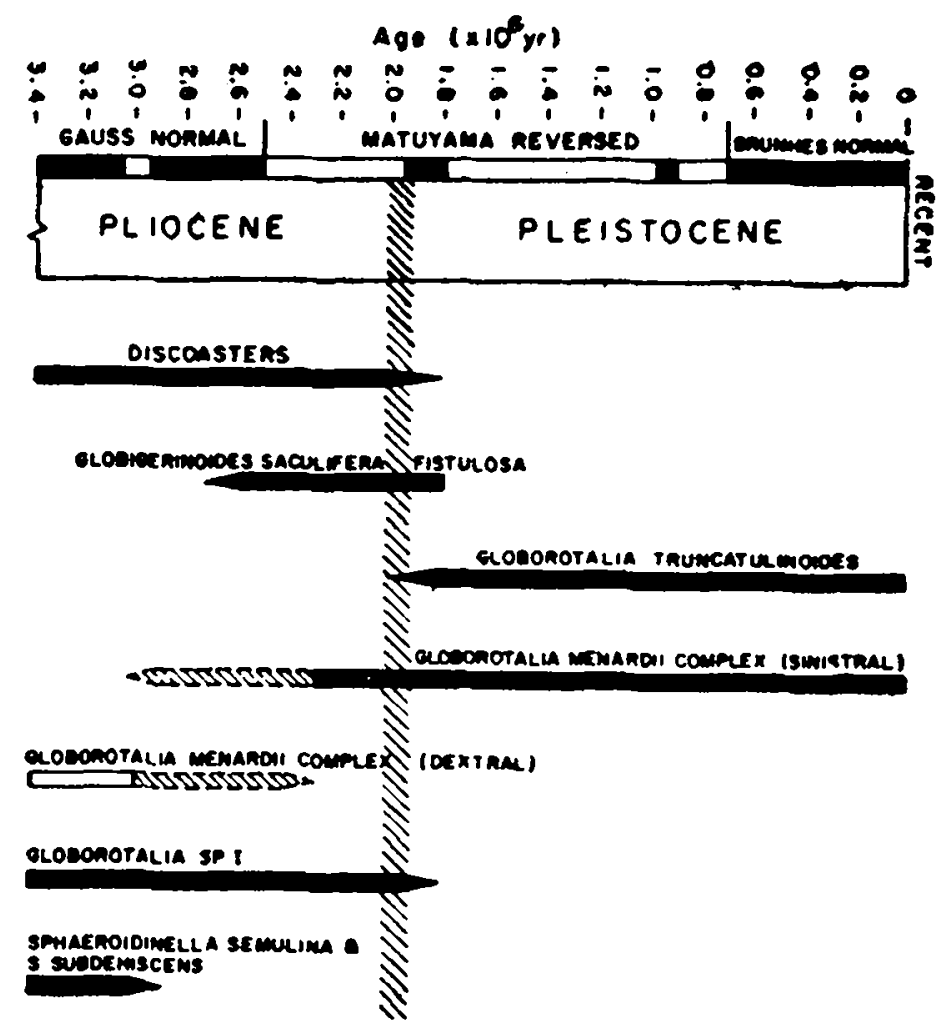

Figure 1. Plio-Pleistocene (N/Q) boundary [hatched] in the marine sediments based on the foraminiferal occurrences and palacomagnetic dating (after Ericson and Wollin 1964.)

(iv) $95 \%$ of the Globorotalia menardii population left coiling above the boundary and $95 \%$ right coiling below the boundary.

(v) Olduvai Event $(1 \cdot 75-1.91 \mathrm{~m} . \mathrm{y}$.) on the magnetic scale.

Some recent and more detailed work has been carried out by Shackleton and Opdyke (1976) on a Pacific Ocean core which goes back to about 2 million years, dated by the recognised magnetic reversals present. Using changes in the oxygen isotope ratios on foraminifera, they find ten pronounced glacial maxima in the last $1 \mathrm{~m} . y$. , followed by less intense, though equal in number, glacial maxima between 2 and $1 \mathrm{~m} . \mathrm{y}$. ago. Thus on the basis of climatic variations alone it is difficult to place the N/Q boundary in the marine sediments at the Olduvai event of $1.75-1.91 \mathrm{~m} . \mathrm{y}$.

\subsection{Continental evidence}

Since the appearance of typical Pleistocene mammals may not be simultaneous all over the world, it is difficult to draw universal $N / Q$ boundary criteria on faunal (mammalian) changes. We will now briefly examine the present status of the $N / Q$ boundary on the main continents. 
The status of the N/Q boundary in the USSR was discussed in detail recently by Dodonov and Penkov (1977) and Gamov and Penkov (1977). These workers prefer the terms Neogene/Anthropogene (figure 2), with Anthropogene further subdivided into Eopleistocene and Pleistocene. The $N / Q$ boundary marks the end of Kuruksay suite and the beginning of Kayrubak suite, comprising the Eopleistocene. The Pleistocene commences with the Vakhsh complex. The extinction of the Kuruksay fauna and the appearance of the Lakhuti fauna coincides with the Kuruksay/Kayrubak suites' boundaries. Ancienı pebble culture appear at the end of the Vakhsh complex.

In North America, faunal stratigraphies are correlated with litho- and magneto- stratigraphies of the Arizona, Texas, California and Kansas deposits Lindsay et al 1975; Johnson et al 1975). The N/Q boundary here probably coincides with the end of the Biancan and the appearance of Irvingtonian land mammals. The Irvingtonian land mammal stage is marked by the presence of Mammuthus, Lepus, Dipodomys and Ondatra, and by the extinction of Stegomastodon. The Biancan/Irvingtonian faunal boundary coincides with the Olduvai Event on the magnetic scale and may therefore mark the $N / Q$ boundary.

In France the Olduvai event on the magnetic scale coincides with the appearance of several new faunal species and the extinction of quite a few, earlier species. For example, the new species that appear around the Olduvai Event are Eucladoceros tetraceros and Cervus perolensis. Cervus elephas

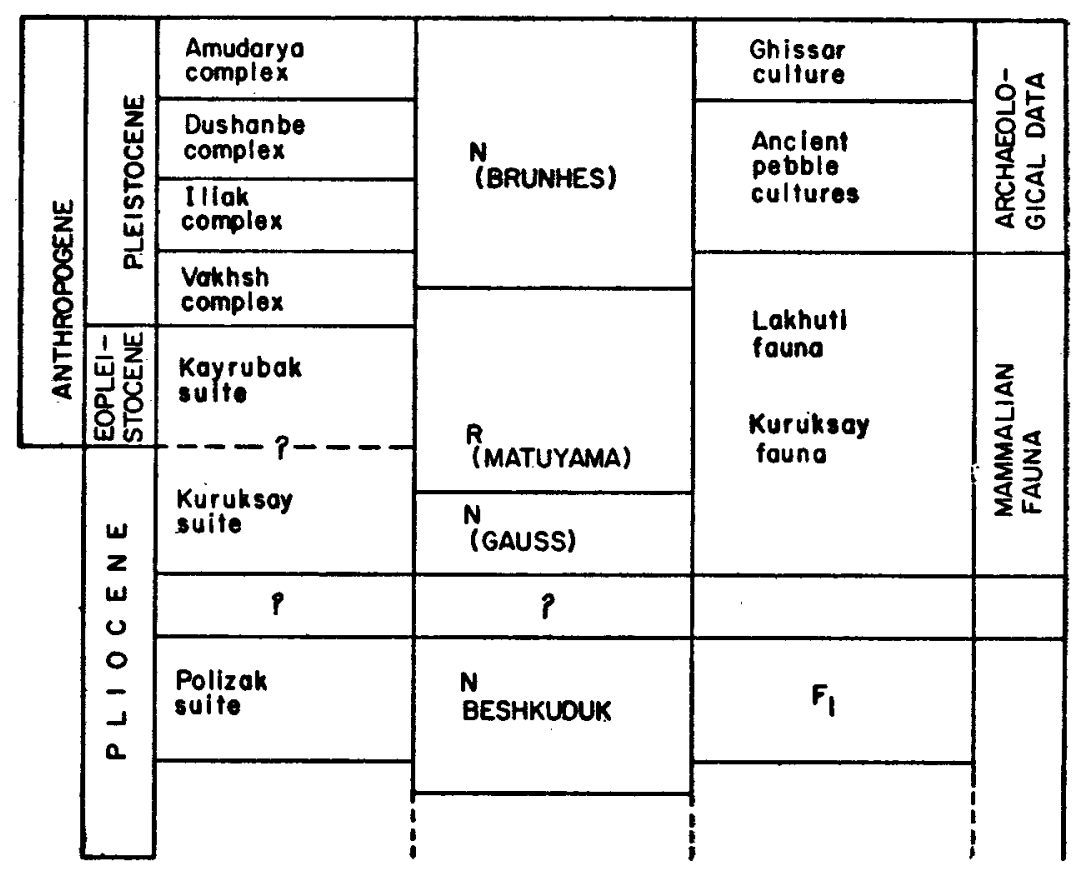

Figure 2. The late Cenozoic magneto-horizons and lithostratigraphic units for Russian Central Asia (after Anon 1977). The Anthropogene starts from the Eopleistocene, a stage between the Pleistocene and Pliocene. 
however, appears only with the commencement of the Brunhes magnetic epoch. The species that come to extinction around the Olduvai event are: Eucladoceros sene, Cervus philisi philisi, Croizet ramosus minor, C. ramosus medius, Gazella and Antilopes. Equus cf. bressanus, however, appears at the Gauss/Matuyama boundary and becomes extinct around the Matuyama/ Brunhes boundary (Bout 1976).

It is thus obvious that it is not possible to define the N/Q boundary which will satisfy a uniform faunal change in all the continents. Climatic oscillations again are not necessarily confined to the Pleistocene and colder periods have occurred even before the Olduvai Event as recorded in deep sea-cores (Shackleton and Opdyke 1976); there are clear indications of cold oscillations starting from the Pliocene times (Lamb 1977). Under the circumstances, the only universal boundary acceptable on a conceptual basis appears to be the one marked by the Olduvai magnetic event.

We shall now examine the status of Neogene/Quaternary transition in both marine and continental deposits from Indian sections.

\section{Indian evidences on $N / Q$ boundary}

\section{1. $N / Q$ bounciary in marine sequences}

In India the late Cenozoic deep water marine facies are well developed in the Andaman-Nicobar islands, and in paralic facies in isolated outcrops along the Kutch-Saurashtra, Kerala and Coromandal coasts.

The first attempt to delineate N/Q boundary in Indian marine sediments was made by Srinivasan and Azmi (1976) and Pandey and Guha (1977). According to Srinivasan and Azmi, the N/Q boundary in the marine sequence of Andaman-Nicobar can be placed at the level of the first appearance of Globorotalia truncatulinoides, which is nearly in agreement with the internationally accepted basal Pleistocene Calabrian stage at Santha Maria di Catanzaro in Southern Italy (Bayliss 1960, 1975).

On the continental shelf of the Bombay coast, the presence of Globorotalia truncatulinoides could not be confirmed (Pandey and Guha, 1977). The assemblage, however, includes some forms of Globigerina calida-praecalida group (late Pliocene-Pleistocene) suggesting a planktonic foraminiferal basis for the N/Q boundary. In the shallower areas, where the planktonic foraminifera are absent, the $N / Q$ boundary becomes highly speculative.

In the Andaman-Nicobar islands, the N/Q boundary is represented by the Taipian (Upper Pliocene) and Shompenian (Pleistocene) stages (Srinivasan 1979). The Taipian stage is defined as extending from the Pulleniatina obliguiloculata-globorotalia multicamerata zone at the base to the Globorotalia tosaensis tenuitheca zone at the top. The Shompenian stage is distinguished by the first appearance of Globorotalia truncatulinoides. Consequently the Taipian-Shompenian boundary is considered as equivalent to the $N / Q$ boundary (figure 3 ).

Ericson and Wollin (1968) had observed, in a number of deep sea cores from the Atlantic and Indian oceans, that Globorotalia menardii complex 


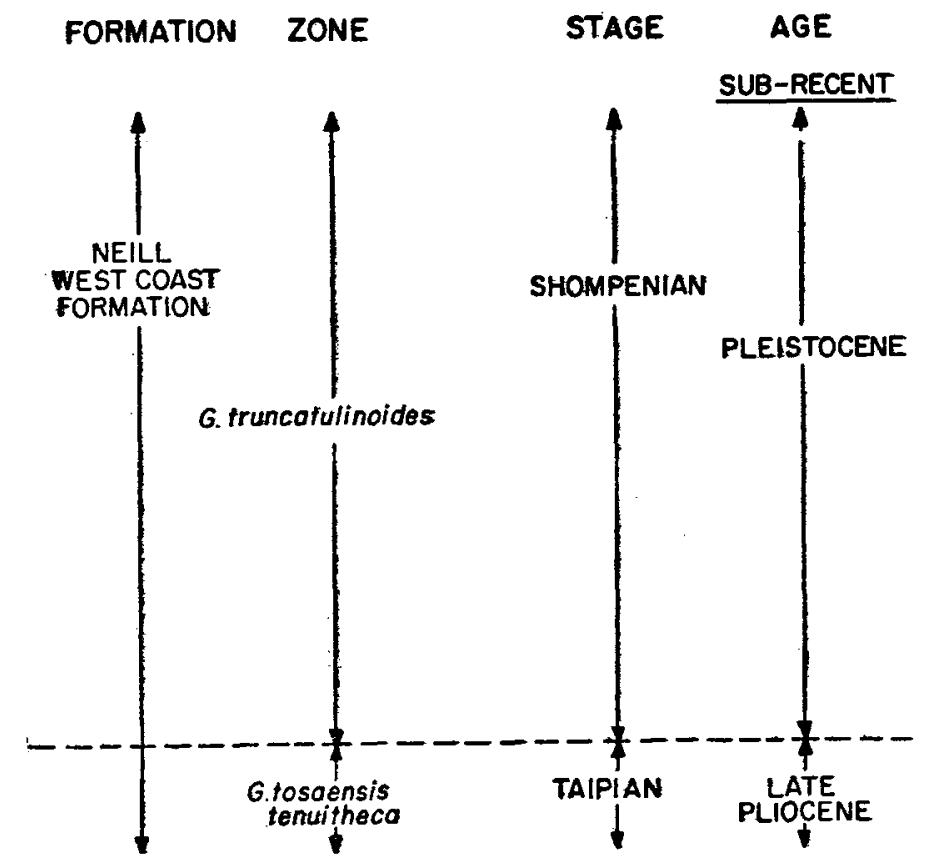

Figure 3. Plio-Pleistocene (N/Q) boundary in the marine sediments of Andaman islands; the N/Q boundary lies between the Taipian and the Shompenian stages (after Srinivasan in Anon 1979).

changed from dextral-coiling to sinistral-coiling above the Plio-Pleistocene boundary, placed at the Olduvai palaeomagnetic event (figure 1).

A similar change was observed by Srinivasan (1979) in $G$. menardii from dextral in Taipian to sinistral in Shompenian. He reported a change in coiling direction in $G$. crassaformis also, from left coiling to right coiling above the $\mathrm{N} / \mathrm{Q}$ boundary. The onset of the Pleistocene is also marked by the appearance of $G$. truncatulinoides in the Andamans. Srinivasan has correlated this event with Zone 22 of Banner and Blow (1965, 1967). In Ericson's scheme also, G. truncatulinoides appears above the Plio-Pleistocene boundary (figure 1). Several planktonic foraminifera such as, G. fistulosus, G. obliquus and Sphaeroidinellopsis seminulina, disappear above the Taipian-Shompenian (N/Q) boundary in the Andamans. So far no radiometric or palaeomagnetic data are available on the Andaman-Nicobar sequences. Efforts are being made to correlate the Andamans and the Karewa sequences with the help of palaeomagnetic dating (D P Agrawal and M S Srinivasan, personal communication).

\section{$4 \cdot 2 N / Q$ boundary in continental deposits}

The outermost sub-Himalayan range of the Himalayan mountain chain was named 'Siwalik' by Cautley. Falconer (1868) dated the rock formations of the Siwalik range as Miocene whereas Lydekker (1874-1887) considered them to be of Pliocene age. It was Pilgrim (1913) who divided the Siwaliks and the contained fauna into the following three divisions (figure 4): 


$\begin{array}{lll}\text { Upper Siwalik } & : & \text { Boulder Conglomerate Zone } \\ & : & \text { Pinjor Zone } \\ \text { Middle Siwalik } & : & \text { Tatrot Zone } \\ & : & \text { Dhok Pathan Zone } \\ \text { Lower Siwalik } & : & \text { Chinji Zone } \\ & : & \text { Kamlial Zone }\end{array}$

Subsequently, several workers have studied the vertebrate fauna from the Siwaliks and as a result the following four views (table 1) have emerged with regard to the placement of the $N / Q$ boundary:

(i) the base of Tatrot Zone on the basis of the presence of Archidiskodon and Leptobos and palaeoclimatic considerations (Mathew 1929; Lewis 1937; De Terra and Paterson 1939; Hooijer and Colbert 1951; and Colbert 1951);

(ii) the base of Pinjor Zone on the basis of the first appearance of Equus in Pinjor (Sahni and Khan 1959; Nanda 1977; Badam 1979);

(iii) the base of Boulder Conglomerate Zone as it represents a change in sedimentation due to climatic deterioration (Pilgrim 1944; Gill 1951; Wadia 1961; Balasundaram and Sastry 1972 and Sastry and Dutta 1977);

(iv) Pinjor as transitional between Pliocene and Pleistocene on the basis of sedimentary, stratigraphic and tectonic considerations (Wadia 1951).

Recently, magnetic polarity measurements on the fossil bearing Upper Siwalik sequence of Pakistan by Opdyke et al (1979) have revised the earlier chronology of the fossil sequence reported by Keller et al (1977). It may, however, be mentioned that whereas Keller et al (1977) based their palaeomag-

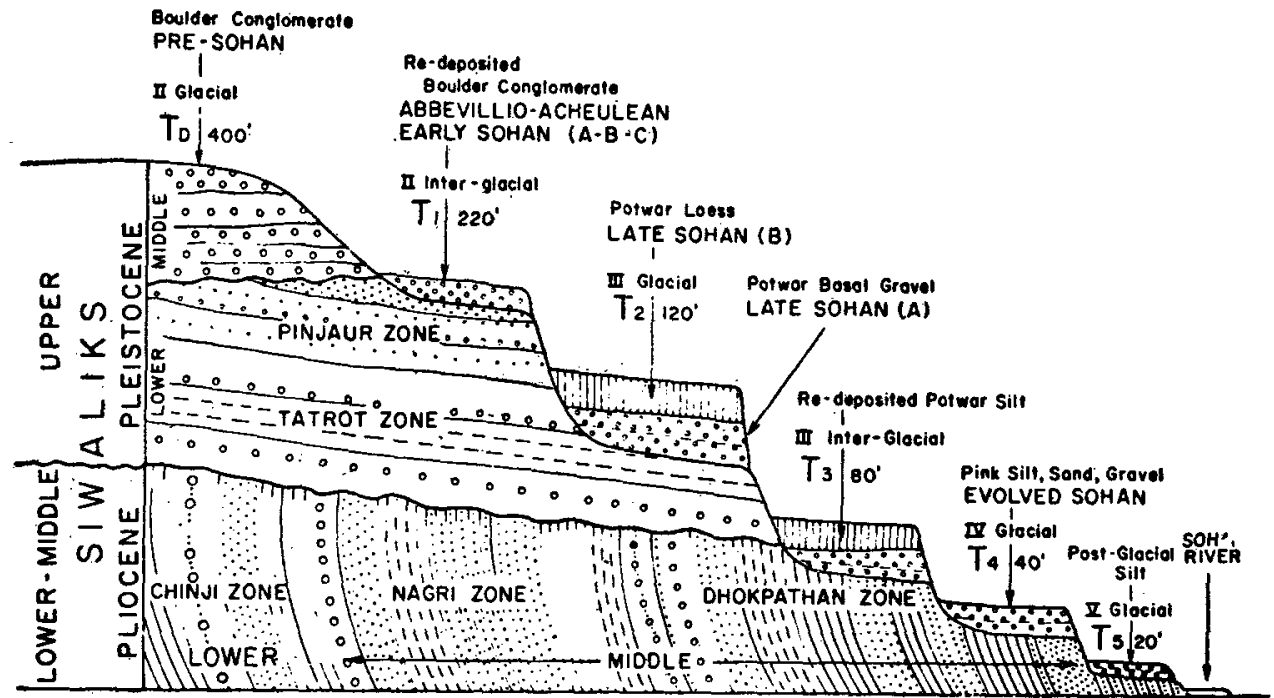

Figure 4. Composite stratigraphic section of the Siwaliks (after De Terra and Paterson 1939; figure 181). Various views on the $N / Q$ boundary are given in table 1 . 


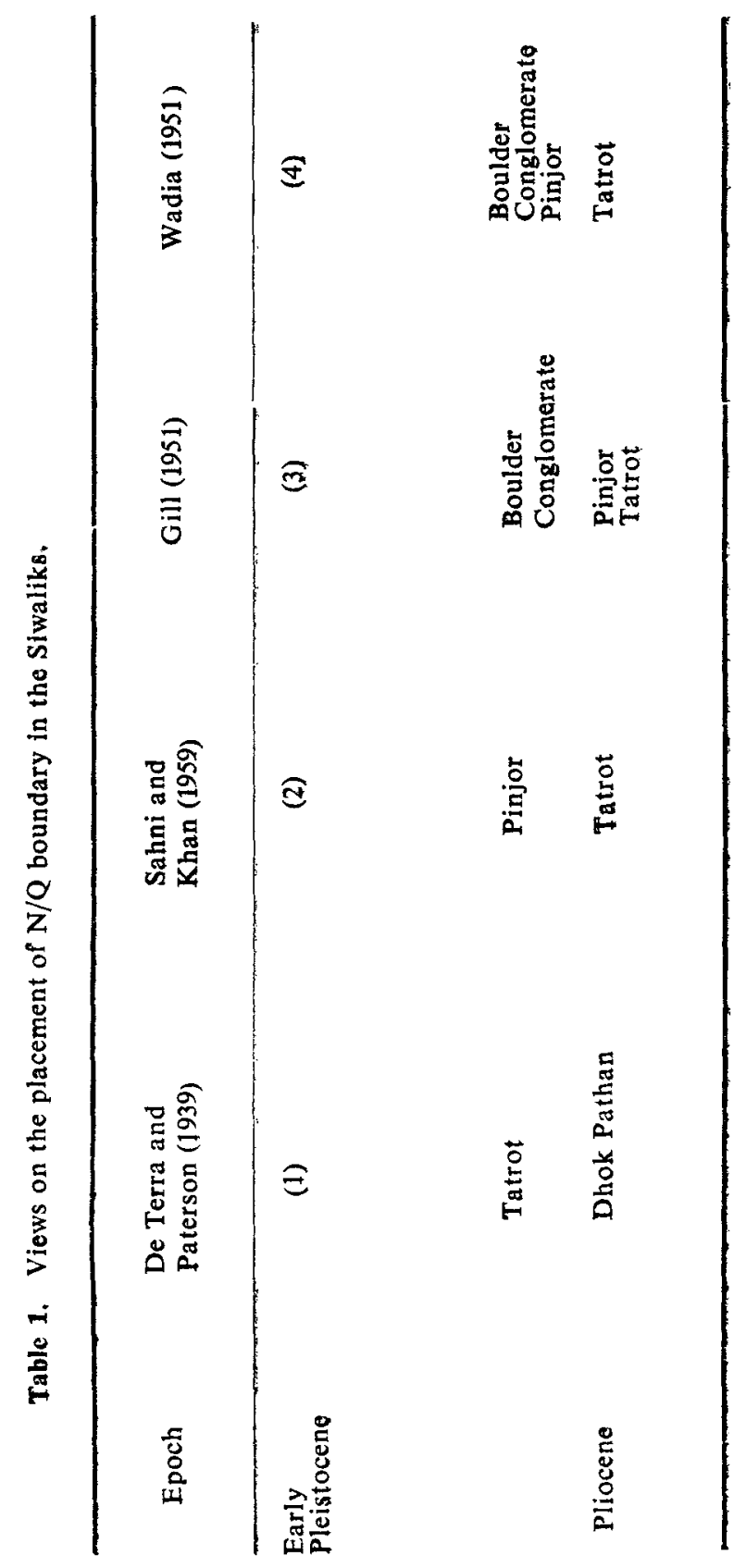


netic studies on the earlier palaeontological work in the area, Opdyke et al (1979) carried out their own palaeontological investigations along with magnetic polarity measurements. Their (Opdyke et al 1979) studies are further supported by fission track dating of zircons from bentonised tuffs appearing below and above the Matuyama/Gauss boundary.

Previously it was reported (Sahni and Khan 1959) that the fossil vertebrate associated with Tatrot at the boundary were Hipparion ( $H$. theobaldi and H. antlopium), Proamphibos (P. kashmiricus), and Archidiskodon planifrons. Appearance of Equus along with Babalus (B. plytyceros) and Rhinoceros (R. sivalensis) demarcated the Tatrot/Pinjor boundary, which coincided with the Olduvai Event. Hipparion was used as a guide fossil by Keller et al (1977) to define Tatrot Zone at Pabbi hills but Opdyke et al (1979) have shown that Hipparion survived into the lowermost Pleistocene, upto a little above the Olduvai Event. It has been further demonstrated that the change of the Tatrot fauna into the Pinjor fauna occurred at about 2.47 m.y. (the Gauss/ Matuyama boundary), based on the simultaneous appearance of Equus, Elephas, Bos and cervids with antlers.

It is interesting to note that Hipparion has also been reported by Satsangi and Dutta (1971) from Pinjor Beds at Haritalyangar.

The Gauss/Matuyama boundary, therefore, appears to coincide with Tatrot/ Pinjor and the Olduvai Event falls within the Pinjor zone representing the $\mathrm{N} / \mathrm{Q}$ boundary. Interestingly, vertebrate fossils of Soricidae, Leporidae, Muridae, Mustelidae, Viverridae, Hayaenidae, Falidae, Machairodontidae and Mammutidae appear just above the Olduvai Event and their presence in older strata has not been recorded.

Thus we see that the so-called Villafranchian fauna, comprising Equus, Elephas and Bos, according to Opdyke et al (1979) appear at $2.47 \mathrm{~m} . \mathrm{y}$. , at the Gauss/Matuyama boundary, and not at the Olduvai Event. If one decides to place the $N / Q$ boundary at the Olduvai Event one will have to use the fauna, emntioned above as the criteria, that appear above this magnetic event.

The Kashmir valley, spread over 5,000 sq.km. in a NW-SE direction, is surrounded by the Great Himalayan range in the NE and the Pir Panjal range in the SW. The rising-up of Pir Panjal by several hundred metres, believed to be during Plio-Pleistocene (Lydekker 1883; Bhatt 1980), gave rise to the formation of a large lake in the valley, and during II Interglacial a tectonic breach drained it out partially (Bhatt 1981).

The Karewas are the sediments that have filled this lake basin during a series of glacial and interglacial events, interrupted by tectonic events that the valley witnessed. Thus, the Karewas, resting over the Palaeozoic avd Triassic basement, are largely lacustrine, glacio-fluvial, tectono-fluvial and fluvial deposits, capped by loessic strata. Two stratigraphic units can be recognised in the Karewa sequence: the lower Hirpur Formation (or 'lower Karewa') and the upper Nagum Formation (or 'upper Karewa'), the two formations are separated by an angular unconformity or a disconformity (Bhatt 1976).

The problem of dating the origin of the Karewa Lake of Kashmir is only beginning to be settled now, as we will briefly discuss below. The age estimates vary from Miocene to Pleistocene times and, therefore, the N/Q boundary problem is also intricately tied down to the date of the origin of the lake. 
We took up the studies of the Karewa sequence, using a multidisciplinary approach, to reconstruct the palaeoclimatic changes in the valley during the late Cenozoic period. To build up a chronology of events we have used a variety of physical techniques like ${ }^{14} \mathrm{C}, \mathrm{U} / \mathrm{Th}$, thermoluminescence, palaeomagnetism, etc. (Pant et al 1978; Agrawal et al 1979 a, b; and Kusumgar 1980). Eut before we discuss our results, we summarize below the views of previous workers on the age of the Karewas.

Lydekker (1883) equated the Karewas with the Upper Siwalik and assigned Pliocene age to them. De Terra and Paterson (1939) assigned them to Pleistocene on the glacial evidence and on the occurrence of Elephas hysudricus in the Hirpurs. They correlated the Hirpurs with the Pinjor Stage of the Upper Siwalik. Middlemiss $(1911,1924)$ ascribed Plio-Pleistocene age to the Karewas-a view also supported by Wadia $(1941,1951)$. Roy (1975) showed that diatoms are restricted to the Hirpurs which could be sub-divided into two biozones, the lower part being characterised by Centrales and the upper part by Pennales. Roy (1975) assigned the Hirpurs to the Miocene. Bhatt and Chatterji (1979a) have, however, upheld the earlier views of Middlemiss and Wadia.

De Terra and Paterson's (1939) lithological zones for the Hirpur sequence have been shown to be not tenable on palynological and field evidences (Vishnu Mittre and Robert 1973; Bhatt 1979). Vishnu Mittre's 1964 work, which combines the inferred climatic episodes with De Terra and Paterson's lithozones, has little significance for the $N / Q$ boundary problem. Bhatt and Chatterji (1979b) have recently rediscussed this problem in the Karewa sequence and have concluded that the $N / Q$ boundary shoul lie in Zone 3 near to its contact with Zone 2 in the Hirpur Formation. The zonal scheme of the Hirpurs followed by them is after Bhatt (1979).

\subsection{Palaeomagnetic measurements}

About 150 palaeomagnetic measurements were carried out on the samples from the Hirpur sequence from Dubjan and Hirpur and the Nagum from Puthkhah, Olchibagh and Saki Paparian; the three latter locations lie on the Himalayan side of the Karewa basin. The three conglomerates at Hirpur (informally numbered as I, II and III in figure 5) were used as stratigraphic markers to control the sampling and for the Nagum sites, marl-beds were used for the same purpose (Agrawal et al 1979; Kusumgar 1980). Except for one of the authors (D K Bhatt), the contacts between Conglomerate III and its underlying and overlying members have not been fully studied in the field.

Whereas all the Nagum samples showed normal magnetisation, at Hirpur below Conglomerate III (figure 5) there is an indication of a distinct signal of reversal in a $10 \mathrm{~m}$ thick section.

On the European analogy (Kukla 1978), we can perhaps assume at this stage that the succession of loess and palaeosols observed by us in the top-most part of the Nagums represents oscillations between glacial and interglacial periods. The top-most palaeosol has been dated by us to $c .18,000$ B. P. and the lower two are older than 31,000 B. P. (Agrawal et al 1979). Palaeomagnetic dating in licates that the Nagums are well within the Brunhes Epoch viz., $<720,000$ 

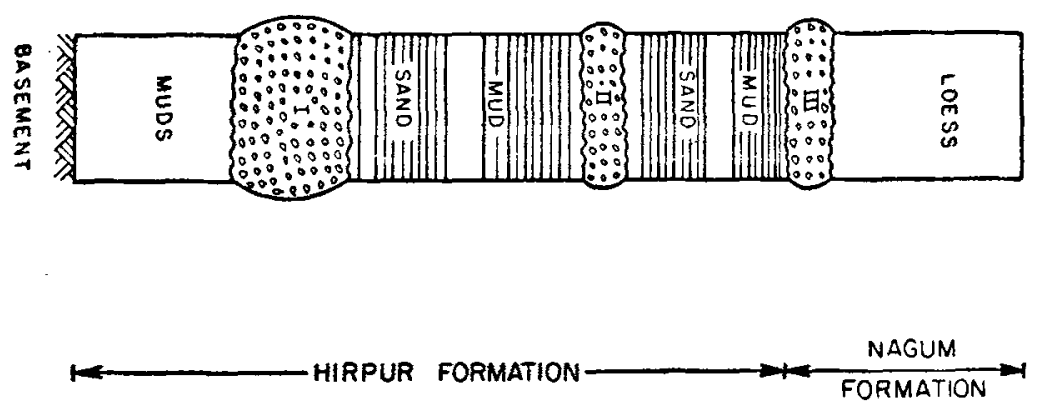

Figure 5. Schematic section of the Karewas in SW Kashmir valley. The three noticeable gravel conglomerates encountered are informally termed I, II and III and have been used as markers for palaeomagnetic sampling at Hirpur. Between Conglomerates (I, II \& III), muds, sands and silts alternate.

B. P. (Kusumgar 1980). The presence of marker fossils below Conglomerate III and a reversed magnetic epoch (Matuyama) indicate that the N/Q boundary must lie between Conglomerates III and II (figure 5). Although a detailed radiometric, palaeomagnetic, sedimentologic and palaeontologic study on the Karewa sequence is still in progress, yet one can arrive at the following tentative conclusions on the basis of the available data (Agrawal et al 1979).

Palaeomagnetic measurements probably indicate that the Nagums are in the Brunhes Normal Epoch $(<720,000$ ); a Matuyama Reversal Epoch was detected in a $10 \mathrm{~m}$ thick deposit below Conglomerate III; most of the sand and mud deposits below and above Conglomerate II indicate Gauss Normal Epoch (2.47-3.41 m. y.); the Gilbert Reversed Epoch (3.41 to $5.44 \mathrm{~m}$. y.) is witnessed above Conglomerate $\mathrm{I}$. This chronology is only preliminary and is subject to revision with our more detailed measurements.

Regarding the palaeomagnetic measurements we would like to point out that so far we have done sampling at wide intervals only. The reversals detected by us have been interpreted as epochs, as in such sampling there is only 1 in 8 chances of detecting the events. But now we have carried out very intensive sampling which will enable us to identify even events. Measurements are in progress.

\section{Conclusion}

From the foregoing, it is obvious that we will have to first define the criteria to demarcate the $N / Q$ boundary in India as elsewhere. As it is difficult to evolve uniform faunal criteria applicable for both marine and continental sequences, it will be better for the time being to take the Olduvai palaeomagnetic event $(1.75-1.91 \mathrm{~m}$. y.) as the N/Q boundary. This will require concerted efforts to evolve a palaeomagnetic stratigraphy for the Siwaliks, the Karewas and the Andaman sequence. We have already initiated palaeomagnetic studies across the $N / Q$ boundary on a sub-continental scale. On the basis of preliminary palaeomagnetic data, the $N / Q$ boundary in Kashmir can 
be recognised between Conglomerates III and Il (figure 5) in the Hirpur Formation and within the Pinjor Stage of the Siwaliks.

In the Andaman-Nicobar marine sequence, the contact between the Taipian and Shompenian stages defines the $N / Q$ boundary.

\section{References}

Agrawal D P, Athavale R N, Krishnamurthy R V, Kusumgar Sheela, Radhakrishnamurthy C and Nautiyal V 1979a Presented at Conference and Field Workshop on the Strati- graphy of Loess and Alluvial Deposits at Budapest, August 1979.

Agrawal D P, Krishnamurthy R V, Kusumgar Sheela, Radhakrishnamurthy $C$ and Nau. tiyal V 1979b Presented at the International Symposium on Neogene-Quaternary Boundary, Chandigarh, October 1979.

Anon 1977 Guide Book (Moscow : International Symposium on the Neogene/Quaternary Boundary).

Anon 1979 Review Papers (Chandigarh : Field Conference on Neogene/Quaternary Boundary, 1979).

Badam G L 1979 Pleistocene Fauna of India (Poona: Deccan College).

Balasundaram M S and Sastry M V A 1972 Rec. Geol. Surv. India 10754

Banner F T and Blow W H 1965 Nature (London) 2031164

Banner F T and Blow W H 1967 Micropaleontology 13133

Bayliss D D 1960 Lethaia 2133

Bayliss D D 1975 Micropaleontology 31

Bhatt D K 1976 Himalayan Geol. 6197

Bhatt D K 1979 Himalayan Geol. 9 (in press)

Bhatt D K 1980 Himalayan Geol. 10 (in press)

Bhatt D K 1981 S. P. Nautiyal Comm. Volume (Dehradun : Himchal Times Press) (in press)

Bhatt D K and Chatterji A K 1979a Geol. Surv. India Misc. Pub. 41191

Bhatt D K and Chatterji A K 1979b Abstract presented at Field Conference Neogene/Quaternary Boundary, Chandigarh, India, 1979

Bout $P 1976$ in La Prehistoire Francaise 1 H. de Lumley (ed.) 362-364 (Paris : CNRS)

Colbert E H 1951 18th Int. Geol. Congr. 1164

De Terra $H$ and Paterson T T 1939 Studies on the ice age in India and associated human culture (Washington: Carnegie Institute)

Dodonov A Y and Penkov A V 1977 Anon 109111

Ericson D B and Wollin G 1964 The deep and the past (New York : Alfred Knopf)

Ericson D B and Wollin G 1968 Science 16212.27

Falconer H 1868 Palaeontological Memoirs I. R I Murchison (ed.)

Gamov L N, Penkov A V 1977 Anon 117.

Gerasimov I P 1979 Boreas 823

Gill W D 1951 Q. J. Geol. Soc. Landon 107249

Hooijer D A and Colbert E H 1951 Am. J. Sci. 249533

Johnson N M, Opdyke N D and Lindsay E H 1975 Ariz. Geol. Soc. Am. Bull. 865

Keller H M, Tahirkheli R A K, Mirza M A Johnson G D, John N M and Opdyke N D 1977 Earth Planet. Sci. Lett. 36187

Kukla G 1978 Trans. Nebr. Acad. Sci. 657

Kusumgar Sheela 1980 Geochronology of the palaeoclimatic events of the late cenozoic period in the Kashmir valley Ph. D. Thesis (Bombay: Bombay University).

Lamb H H 1977 Climate: present, past and future (London: Methuen) Vol. 2

Lewis G E 1937 Am. J. Sci. 5191

Lindsey E H, Johnson N M and Opdyke N D 1975 Claude W. Hibbard Mem. Vol. 3 (ed) G R Smith and N E Friedland (Univ. of Michigan)

Lydekkar R D 1874-87 Palaeont. India Series X 1-4

Lydekker F 1883 Indian Geal. Survey Mem. 22 1-344 
Lyell C 1833 Principles of geology 3 (London : John Murray) 398

Lyell C 1839 Mag. Nat. History 3113

Mathew W D 1929 Bull. Am. Mus. Nat. Hist. 56437

Middlemiss C S 1911 Rec. Geol. Soc. India 41115

Middlemiss C S 1924 Rec. Geol. Soc. India 55241

Nanda A C 1977 Colloques International du Centre National de La Recherche Scientifique No. 268. Himalayan Science de la Terra, Paris, December 1976, 514

Opdyke N D, Lindsay E, Johnson G D, Johnson N, Tahirkheli R A K and Mirza M A 1979 Palaeogeogr. Palaeoclimatol. Palaeoecol. 271

Pant R K, Agrawal D P and Krishnamurthy R V 19/8 In Scanning electron microscopy in the study of sediment (ed.) W B Whalley (Norwich: Geo Abstracts)

Pandey J and Guha D K 1977 Presented at the National Seminar on Quaternary environment with special reference to Western India, Baroda

Pilgrim G E 1913 Rec. Geol. Surv. India 43264

Pilgrim G E 1944 Geol. Mag. 8128

Roy D K 1975 Geol. Surv. India Misc. Publ. 24204

Sahni M R and Khan E 1959 J. Palaeontol. Soc. India 461

Sastry M V A and Dutta A K 1977 G. Geol. (2) XLI, Face I-II 331-340

Satsangi P P and Dutta A K 1971 Rec. Geol. Surv. India 101193

Shackleton N J and Opdyke N D 1976 Geol. Soc. Am. Mem. 145449

Srinivasan M S 1979 Anon

Srinivasan M S and Azmi R J 1976 Proc. VI Indian Colloquium on Micropaleontology and Stratigraphy 283-309

Wadia D N 1941 Proc. Nat. Inst. Sci. 719

Wadia D N 1951 Int. Geo. Congr. 243

Wadia D N 1961 Geology of India (London: MacMillan \& Co.)

Vishnu-Mittre 1964 Palaeobotanist 12270

Vishnu-Mittre and Robert R 1973 Palaeobotanist 20 344-355 